\title{
On the Debye temperature in the Slack approximation for an estimation of the thermal conductivity of nonmetallic compounds
}

Citation for published version (APA):

Bruls, R. J., Hintzen, H. T. J. M., \& Metselaar, R. (2005). On the Debye temperature in the Slack approximation for an estimation of the thermal conductivity of nonmetallic compounds. Journal of Applied Physics, 98(12), 126101-1/2. [126101]. https://doi.org/10.1063/1.2148625

DOI:

$10.1063 / 1.2148625$

Document status and date:

Published: 01/01/2005

Document Version:

Publisher's PDF, also known as Version of Record (includes final page, issue and volume numbers)

Please check the document version of this publication:

- A submitted manuscript is the version of the article upon submission and before peer-review. There can be important differences between the submitted version and the official published version of record. People interested in the research are advised to contact the author for the final version of the publication, or visit the $\mathrm{DOI}$ to the publisher's website.

- The final author version and the galley proof are versions of the publication after peer review.

- The final published version features the final layout of the paper including the volume, issue and page numbers.

Link to publication

\footnotetext{
General rights

- You may freely distribute the URL identifying the publication in the public portal. follow below link for the End User Agreement:

www.tue.nl/taverne

Take down policy

If you believe that this document breaches copyright please contact us at:

openaccess@tue.nl

providing details and we will investigate your claim.
}

Copyright and moral rights for the publications made accessible in the public portal are retained by the authors and/or other copyright owners and it is a condition of accessing publications that users recognise and abide by the legal requirements associated with these rights.

- Users may download and print one copy of any publication from the public portal for the purpose of private study or research.

- You may not further distribute the material or use it for any profit-making activity or commercial gain

If the publication is distributed under the terms of Article 25fa of the Dutch Copyright Act, indicated by the "Taverne" license above, please 


\title{
On the Debye temperature in the Slack approximation for an estimation of the thermal conductivity of nonmetallic compounds
}

\author{
R. Bruls, H. T. Hintzen, and R. Metselaar \\ Laboratory of Solid State and Materials Chemistry, Eindhoven University of Technology, P.O. Box 513, \\ 5600 MB Eindhoven, The Netherlands
}

(Received 31 May 2005; accepted 8 November 2005; published online 20 December 2005)

\begin{abstract}
The value of the Debye temperature of the acoustic modes, as required in the application of Slack's approximation [G. A. Slack, Solid State Physics, edited by F. Seitz, D. Turnbull, and H. Ehrenreich, (Academic, New York, 1979), Vol. 34, pp. 1-71] for the thermal conductivity, is not always available. It is shown that for these cases, the value at the minimum of the curve of the Debye temperature versus the temperature obtained from specific-heat data, gives a good approximation. (c) 2005 American Institute of Physics. [DOI: 10.1063/1.2148625]
\end{abstract}

In the literature of inorganic compounds there is a constant flow of papers on materials with unknown properties, particularly of nonoxidic materials. Since in general the measurement of physical data, such as electrical, thermal, and mechanical properties, is only possible when dense solid materials are available, estimates, even relatively crude ones, are of great value for the experimentalist. For an estimate of the thermal conductivity of nonmetallic compounds, the most widely used approximation is the equation given by Slack: ${ }^{1}$

$$
K^{\prime}\left(\widetilde{\theta}_{\infty}\right)=B n^{1 / 3} \bar{M} \delta \widetilde{\theta}_{\infty}^{2} \gamma_{\infty}^{-2} .
$$

In this equation, the following symbols are used: $K^{\prime}\left(\tilde{\theta}_{\infty}\right)$ is the estimated thermal conductivity at temperature $T=\widetilde{\theta}_{\infty}, B$ is a constant, $n$ is the number of atoms per primitive unit cell, $\bar{M}$ is the average atomic mass of the crystal, $\delta^{3}$ is the average volume occupied by one atom of the crystal, $\theta$ is the Debye temperature, and $\gamma$ is the thermodynamic Grüneisen constant. It has been shown that the $\theta$ to be used in Eq. (1) should be the Debye temperature for the three acoustic branches only. ${ }^{1,2}$ Following Slack, ${ }^{1}$ we indicate this value by $\widetilde{\theta}_{\infty}$, and it can be obtained from the phonon density-of-states (DOS) function $g(\nu)$ according to the equation

$$
\widetilde{\theta}_{\infty}^{2}=\frac{5 h^{2}}{3 k^{2}} \frac{\int_{0}^{\infty} \nu^{2} g(\nu) d \nu}{\int_{0}^{\infty} g(\nu) d \nu},
$$

where $h$ is Planck's constant, $k$ is Boltzmann's constant, $\nu$ is the phonon frequency, and the integration is only over the acoustic branches of the phonon spectrum. The value for the acoustic branch at $0 \mathrm{~K}$ is $\tilde{\theta}_{0}$. This quantity is related to the usual $\theta_{0}$ obtained from the elastic constants or by extrapolation of specific-heat data by

$$
\tilde{\theta}_{0}=\theta_{0} n^{-1 / 3} .
$$

There are several problems in the application of Eq. (1). The first one is that accurate values for the Grüneisen constant are often not available. More important, phonon DOS curves are generally absent, in particular for recently synthesized compounds. Even if DOS curves are available from inelastic neutron scattering experiments, these curves have to be corrected for the frequency-dependent neutron cross sections. An extra complication for the interpretation of the DOS curves is the often occurring overlap of phonon branches. In practice, this means that for the interpretation of the experimental data one always needs lattice dynamics calculations or other theoretical approaches.

Given the approximations in Eq. (1), one should look for the most simple approach of the theta value in this equation. Since the specific heat $C_{p}$ can be measured relatively easily as soon as powders are available, $C_{p}-T$ curves can often be found in literature. These data are then used to calculate the Debye temperature as a function of temperature, although the restrictions mentioned above also hold for the calculations of these curves. However, the values of $\tilde{\theta}_{0}$ or $\tilde{\theta}_{\infty}^{c v}$ derived from these curves often differ considerably from $\tilde{\theta}_{\infty}$. In this article, we show that a better approximation is obtained by using the Debye temperature $\theta_{\min }$ at the minimum of the curve of the specific heat versus temperature. Examples are shown in Table I. The reason for this can be understood by comparing the Debye DOS curves with real phonon DOS curves. At low temperatures, only the low-frequency part of the DOS, i.e., the acoustic modes, contributes to the specific heat. In this region, the Debye DOS is always lower than the real DOS and the difference first increases with increasing frequencies.

TABLE I. Values of the Debye temperatures of several compounds (numbers in brackets indicate references).

\begin{tabular}{lrrrr}
\hline \hline Crystal & $\tilde{\theta}_{0}(\mathrm{~K})$ & $\tilde{\theta}_{\infty}^{c v}(\mathrm{~K})$ & $\tilde{\theta}_{\text {min }}(\mathrm{K})$ & $\tilde{\theta}_{\infty}(\mathrm{K})$ \\
\hline $\mathrm{Si}$ & $512[1]$ & $535[3]$ & $366[3]$ & $395[1]$ \\
$\mathrm{Ge}$ & $297[1]$ & $313[3]$ & $203[3]$ & $235[1]$ \\
$\mathrm{Diamond}$ & $1778[1]$ & $1485[4]$ & $1468[4]$ & $1450[1]$ \\
$\mathrm{GaAs}$ & $275[1]$ & $299[1]$ & $198[1]$ & $220[1]$ \\
$\mathrm{MgO}$ & $750[1]$ & $618[5]$ & $601[5]$ & $600[1]$ \\
$\mathrm{LiH}$ & $944[1]$ & $928[6]$ & $635[6]$ & $615[1]$ \\
$\mathrm{NaCl}$ & $256[1]$ & $223[7]$ & $218[7]$ & $220[1]$ \\
$\mathrm{SiC}$ & $898[1]$ & $923[8]$ & $750[8]$ & $740[1]$ \\
$\mathrm{Si}_{3} \mathrm{~N}_{4}$ & $396[9]$ & $498[9]$ & $347[9]$ & $370[10]$ \\
\hline \hline
\end{tabular}


The Debye temperature is determined by the difference in the integral in the numerator of Eq. (2) for the Debye DOS and the real DOS. As a result, the Debye temperature decreases until the difference between these integrals starts to decrease. Consequently, a minimum is found in the curve of the Debye temperature as a function of temperature, and in first approximation this occurs where the contribution of the acoustic modes decreases and/or the contribution of the optic modes increases. Although there is no strict relation between $\tilde{\theta}_{\infty}$ and $\tilde{\theta}_{\text {min }}$, Table I shows that the value obtained from the minimum is generally much closer to $\tilde{\theta}_{\infty}$ than the values at $0 \mathrm{~K}$ or at the high-temperature limit of the $\theta-T$ curve.

We have used this approximation for the case of $\mathrm{MgSiN}_{2}$. For this compound, $C_{V^{-}} T$ data are available, ${ }^{11}$ from which we calculate the following Debye temperatures: $\tilde{\theta}_{0}$ $=357 \mathrm{~K}, \tilde{\theta}_{\infty}^{c v}=395 \mathrm{~K}$ and $\tilde{\theta}_{\min }=294 \mathrm{~K}$. Using the $\tilde{\theta}_{\min }$ value in Eq. (1), we obtain a thermal conductivity at $T=294 \mathrm{~K}$ of $30 \mathrm{~W} / \mathrm{mK}$, whereas $\tilde{\theta}_{0}$ leads to an estimated value of $55 \mathrm{~W} / \mathrm{mK}$. The experimental value reported up to now at room temperature is $23 \mathrm{~W} / \mathrm{mK}$. An alternative estimate can be obtained from the experimentally determined relation between thermal diffusivity and temperature. ${ }^{11}$ This leads to an estimated maximum value of $28 \mathrm{~W} / \mathrm{mK}$. Obviously, the minimum Debye temperature gives a better estimate of the thermal conductivity.

Within the approximations of Eq. (1), we conclude that in cases in which more accurate data for the Debye temperature of the acoustic modes are not available, the value at the minimum in the curve of $\theta$ as a function of temperature is a good choice.

${ }^{1}$ G. A. Slack in Solid State Physics, edited by F. Seitz, D. Turnbull, and H. Ehrenreich (Academic, New York, 1979), Vol. 34, pp. 1-71.

${ }^{2}$ B. Billard and F. Cabannes, High Temp. - High Press. 3, 201 (1971).

${ }^{3}$ P. Flubacher, A. J. Leadbetter, and J. A. Morrison, Philos. Mag. 4, 273 (1959).

${ }^{4}$ G. Dolling and R. A. Cowley, Proc. Phys. Soc. London 88, 463 (1966).

${ }^{5}$ T. H. K. Barron, W. T. Berg, and J. A. Morrison, Proc. R. Soc. London, Ser. A 250, 70 (1959)

${ }^{6}$ B. Yates, G. H. Wostenholm, and J. L. Bingham, J. Phys. C 7, 1769 (1974).

${ }^{7}$ T. H. K. Barron, W. T. Berg, and J. A. Morrison, Proc. R. Soc. London, Ser. A 242, 478 (1957).

${ }^{8}$ G. L. Humprey, S. S. Tod, J. P. Coughlin, and E. G. King, US Bur. Mines, BM-RI-488, Vol. 1, 1952 as cited in Y. S. Touloukian and E. H. Buyco, Thermophysical Properties of Matter (Plenum, New York, 1970), Vol. 5, p. 448 .

${ }^{9}$ C. K. Loong, P. Vashista, R. K. Kalia, and I. Ebbsjo, Europhys. Lett. 31, 201 (1995)

${ }^{10}$ R. J. Bruls, H. T. Hintzen, G. de With, R. Metselaar, and J. C. van Miltenburg, J. Phys. Chem. Solids 62, 783 (2001).

${ }^{11}$ R. J. Bruls, H. T. Hintzen, and R. Metselaar, J. Eur. Ceram. Soc. 25, 767 (2005). 